\title{
CONSCIENCE AND SELFHOOD: THOMAS MORE, JOHN HENRY NEWMAN, AND THE CRISIS OF THE POSTMODERN SUBJECT
}

\author{
TERRENCE MERRIGAN
}

\begin{abstract}
Both Thomas More and John Henry Newman understood the human subject as a historically situated, responsible, and dynamic being that realizes itself through conscientious moral action amid the ambiguities of history. Both men were also obliged to come to terms with the tensile relationship between loyalty to conscience and loyalty to tradition. Their lives and their work would seem to resonate with, and constitute a challenge to, the contemporary postmodern debate about the nature of selfhood.
\end{abstract}

$\mathrm{T}$ Homas More (1478-1535) and John Henry Newman (1801-1890) lived very different lives, confronted very different challenges, and died very different deaths. Nevertheless, a convincing case can be made for the claim that the premodern More and the modern Newman shared essentially the same worldview, and that this worldview is relevant to our postmodern age. It is not merely that their shared worldview was thoroughly Christian (and Catholic); it was also possessed of certain distinctive features that mark them out as soul mates, so to speak, and, as far as our age is concerned, perhaps even as prophets and guides. These distinctive features are located in their understanding of both the nature of the self and the achievement of authentic selfhood. More specifically, both men understood the self or the subject ${ }^{1}$ primarily as a being that realizes itself through conscientious moral action within the framework of a history that

Terrence Merrigan received his STD from the Catholic University of Leuven, where he is now professor of systematic theology. Specializing in the theology of Newman, interreligious dialogue, and Christology, he has recently edited two volumes: The Cambridge Companion to John Henry Newman (with Ian Ker, 2009); and "Godhead Here in Hiding": Incarnation and the History of Human Suffering (2012). In progress is a monograph on the contemporary experience of secularization in the light of Newman's understanding of religion.

${ }^{1}$ For the purposes of this article, I use the words "self" and "subject" as synonyms. My source in this regard is Nick Mansfield, Subjectivity: Theories of the Self from Freud to Haraway (New York: New York University, 2000). Mansfield uses "subject" as "the term . . . to describe interior life or selfhood, especially as it is theorized in terms of its relationship to gender, power, language, culture and politics, etc." (185, emphasis original; see also 3$)$. 
is inevitably-even necessarily_ambiguous. Their views in this regard enabled them to come to terms with the turmoil of their times. Perhaps their wisdom and experience can illuminate and even help us come to terms with the turmoil of our own times.

In what follows, I examine the parallels between these two great Christian thinkers and the lessons they might be able to teach us.

\section{THE PERCEPTION OF THE SELF IN MORE AND NEWMAN}

\section{More, Newman, and the "Catholic Continuum"}

In his "Preface to A Man for All Seasons," Robert Bolt declared that in the course of the play's composition,

Thomas More became for [him] a man with an adamantine sense of his own self. He knew where he began and left off, what area of himself he could yield to the encroachments of his enemies, and what to the encroachments of those he loved. It was a substantial area in both cases [and] . . . he was able to retire from those areas in wonderfully good order, but at length he was asked to retreat from that final area where he located his self. And there this supple, humorous, unassuming and sophisticated person set like metal, was overtaken by an absolutely primitive rigour, and could no more be budged than a cliff. ${ }^{2}$

Bolt has been taken to task for his portrayal of More as a man who regarded the "self" as the arbiter of what is true and good, but the playwright recognized that More's "self" is far removed from the modern subject who has nothing against which to measure himself and is therefore susceptible to allowing himself to be determined by others (and the market in particular). Indeed, reflecting on the plight of the modern self, whom he describes as caught up in "an accelerating flight to the periphery, leaving a centre which is empty when the hours of business are over," Bolt observes that "it may be that a clear sense of the self can only crystallize round something transcendental." ${ }^{3}$ For Bolt, More is obviously a case in point. Newman, I will argue, constitutes another case. What makes both men especially interesting, however, is their realization that the transcendental is, as it were, given in the discovery of selfhood, that God is indeed intimior intimo meo such that the journey toward selfhood will be religious, or it will be futile.

2 Robert Bolt, "Preface to A Man for All Seasons," in Essential Articles for the Study of Thomas More, ed. Richard S. Sylvester and Germain Marc'hadour (Hamden, CT: Archon, 1977) 473-80, at 476. For a critical assessment of Bolt's presentation, see Anthony Kenny, Thomas More, Past Masters (New York: Oxford University, 1983) 93-97, at 94. John Guy, Thomas More (London: Arnold, 2000) 186 , takes a similar line.

3 Bolt, "Preface to A Man for All Seasons" 476-77, emphasis original. 
As observed above, More and Newman lived in very different times. This means that their thinking was shaped by very different presuppositions or, to use Newman's terminology, "first principles." ${ }^{4}$ Whereas More could, at least initially, presume upon a deeply rooted and broadly shared consensus on matters of faith and authority, Newman was profoundly aware of the increasing fragmentation of the public mind and the steadily declining role of religion in shaping thought and public life. It is not surprising, then, that while More's initial attempts to defend orthodoxy were rooted in an appeal to the "common faith" of Christendom, Newman's apologetic takes as its starting point the individual's encounter with God in conscience.

Shared tradition and individual conscience might be regarded as two points on a sort of Catholic continuum, along which both men moved as the times required a particular response. The Catholic genius of both More and Newman, it might be argued, consisted of their ability to sustain the inevitable tension that life on such a continuum brings with it. Both men bear witness to the "polar" dynamic that is so basic to Catholic life, ${ }^{5}$ namely, the quest to hold in tensile unity the responsibility for one's self and the responsibility toward the community of faith. Once this polar dynamic is recognized and understood, the paradoxes (or even aporias) that trouble students of More and of Newman can be resolved. So, for example, critics of More seek to debunk the claim that he is a paradigm of the rights of conscience by pointing to his determination to shape conscience by reference to the Catholic tradition. ${ }^{6}$ In the same way, Newman's defence of conscience is often invoked to argue the case for the priority of individual judgment over tradition. Both positions fail to do justice to the determination of both men to acknowledge—and even exploit— the "polar" tension between self and community that is basic to the Catholic mind.

\section{Thomas More on Conscience and Selfhood}

As already noted, for most of his life Thomas More could presume upon the Catholic synthesis and the universal claims of the Roman Catholic

${ }^{4}$ In his discussion of first principles, Newman anticipated a great deal of what Hans-Georg Gadamer would write in Truth and Method regarding "prejudice" (Vorurteil) and tradition. See Thomas K. Carr, Newman and Gadamer: Toward a Hermeneutics of Religious Knowledge (Atlanta: Scholars, 1996) 103-10.

${ }^{5}$ For a discussion of the notion of polarity in reference to the church, see Terrence Merrigan, Clear Heads and Holy Hearts (Grand Rapids, MI: Eerdmans, 1991) 16-17. The notion of polarity involves positing a tensile relationship between the component elements of a phenomenon. These elements are regarded as opponent and oppugnant, but not contrary. They are engaged in continual dialectical interplay with one another. This interplay may give rise to either dynamic unity-in-tension or imbalance and paralysis.

${ }^{6}$ See Terrence Merrigan, "Newman and Theological Liberalism," Theological Studies 66 (2005) 605-21. 
Church that were characteristic of the Middle Ages. This is not to suggest that More was an Ultramontane avant la lettre. A year before his execution, he explained that there had been a time when he did not regard papal primacy as divinely instituted. His views had begun to change once the issue of authority had been raised to the top of the theological agenda by the Protestant Reformers-Martin Luther in particular. ${ }^{7}$ More's mature view was the fruit of "many years" of study and deliberation, ${ }^{8}$ during which, as he put it, he had "not informed his conscience either suddenly or lightly, but by long leisure and diligent search for the matter." ${ }^{\circ} \mathrm{He}$ insisted that, in every case where one's salvation is at stake, it is a person's duty "to examine [his or her] conscience surely by learning and by good counsel." ${ }^{10}$ His own decision to risk death was, he explained, the fruit of "reason with help of faith."11

Reason included the consideration of the "mind of the Church" as this was manifest throughout history. The mind of the church might be disclosed in either a "general council or ... a general faith grown by the working of God universally through all Christian nations." $"$ Manifest in both cases is the consensus of the whole church regarding a point of doctrine or practice. Such consensus is normally apparent even before the point is raised (though it may emerge subsequently). ${ }^{13}$ More came to the conclusion that the primacy of the pope was the object of such prior, albeit implicit, consensus. ${ }^{14}$ Once he had done so, he felt himself bound by conscience to affirm it, at least when all the legal grounds for his refusal to disclose his

${ }^{7}$ See Alvaro De Silva, ed., The Last Letters of Thomas More (Grand Rapids, MI: Eerdmans, 2000) 53-54.

8 Ibid. 74.

9 Ibid. 60. His own conscience, he insisted in other letters, was "informed" by diligent reflection over an extended period of time (121).

10 Ibid. 106.

11 Ibid. 101.

12 Ibid. 83. More also speaks variously of "the general council of Christendom" (60), "the general council of the whole body of Christendom," the "whole catholic church lawfully gathered together in a general council" (82-83), "a well assembled general council" (84), "the common faith of Christendom" (84), "a general council" (94), and "the whole corps [= corpus] of Christendom" (120). For a more detailed consideration of More's thought on the "mind of the church," see Philip Sheldrake, "Authority and Consensus in Thomas More's Doctrine of the Church," Heythrop Journal 20 (1979) 146-62. See also Richard C. Marius, "Henry VIII, Thomas More, and the Bishop of Rome," in Quincentennial Essays on St. Thomas More, ed. Michael J. Moore (Boone, NC: Albion, 1978) 89-107, at 105-6. John Guy, Thomas More (London: Arnold, 2000) 201-4.

13 Sheldrake, "Authority and Consensus" 159, 162. More understood this consensus to be the fruit of the Holy Spirit. See also Peter Marshall, "The Last Years," in The Cambridge Companion to Thomas More, ed. George M. Logan (New York: Cambridge University, 2011) 116-38, at 122-23, 136.

14 Marius, "Henry VIII, Thomas More and the Bishop of Rome" 90; Marshall, "Last Years" 134-35. 
own mind on the matter had been eroded. More's reluctance to make his position clear was not a matter of cowardice; it was inspired by his fear of courting martyrdom. ${ }^{15}$ When he had done all he could reasonably do to avoid execution, the options were quite straightforward. He could act, as he put it, against his conscience and lose his soul, or according to his conscience and lose his body. Later he declared that the options were beheading and hell. ${ }^{16} \mathrm{He}$ was aware, he said elsewhere, that he "must make answer unto God" for his own conscience, and that the answer others gave was a matter for themselves. ${ }^{17}$

Commentators on More's decision have understood it in a variety of ways. So, for example, one of More's earliest modern biographers saw it as the affirmation of "the right of individual conscience, as against the state."18 Recent commentators have understood it as, among other things, a manifestation of More's fear that telling a lie would "imperil his immortal soul"19 or, more positively, as an expression of his loyalty to the "sacral church" 20 or to the "common faith of Christendom." ${ }^{21}$ Bolt regarded it as the assertion of the "self," a declaration that the irreducible self really does exist. ${ }^{22}$

While Bolt's view does betray a certain degree of modern "subjectivism," his portrayal of "selfhood" as an intense "self-awareness" does in fact resonate with notions of self-consciousness prevalent in More's time. Richard Sylvester has pointed out that the 16th-century usage of the word "conscience" always involved and indeed

emphasize[d] the root scientia, knowledge in and of itself . .., but this knowledge can either relate to personal, and particularly moral, convictions (our own modern meaning), or it can be knowledge directed outward, a consciousness of the world and of others. The word consciousness itself does not appear in English until the late seventeenth century. In More's own day, as in both classical and medieval Latin and in modern French, conscience had for long meant both moral conviction and personal awareness.

15 See Clarence H. Miller, "The Heart of the Final Struggle: More's Commentary on The Agony in the Garden," in Quincentennial Essays on St. Thomas More 108-23, at 122. See also Marshall, "Last Years" 121-23, 136.

16 De Silva, Last Letters 120; see also 58, 60.

17 "I would ... . for mine own self follow mine own conscience, for which myself must make answer unto God, and ... leave every other man to his own conscience" (ibid. 94; see also 64-65, 101).

18 R. W. Chambers, Thomas More (London: Jonathan Cape, 1957) 400; see also 396.

19 Jasper Ridley, The Statesman and the Fanatic: Thomas Wolsey and Thomas More (London: Constable, 1982) 291.

20 Richard Marius, Thomas More: A Biography (Cambridge, MA: Harvard University, 1984) 517.

21 Guy, Thomas More 222.

22 Bolt, "Preface to A Man For All Seasons" 477. 
In the end, Sylvester notes, More's "conscience and consciousness were one." 23

In the final analysis, though, as Clarence Miller declared on the 500th anniversary of More's birth, "More did not die for any principle, or idea, or tradition, or even doctrine, but for a person, for Christ." According to Miller, this is made overwhelmingly clear in the three works More completed while he was a prisoner in the Tower of London (they are collectively referred to as the Tower Works). In these writings, More meditates, respectively, on Christ's presence in the Eucharist, his physical sufferings on the cross, and his spiritual torments in Gethsemane. ${ }^{24}$ In each case, the significance of Christ's sufferings for his extended body, the church, is unfolded. Indeed, "the common thread running through More's writings from the Tower is his unshakeable belief in the unity of Christ's body." For More, then, assaults on the physical body of Christ "were but the prototype of assaults against his sacramental body in the Eucharist or against faithful members of his mystical body the church." 25

It is possible to see each of the three Tower Works as representing a facet of More's comprehensive witness to his faith. He writes, respectively, as an apologist, a prisoner, and a "reluctant martyr." ${ }^{\text {,6 }}$ In each case, his ultimate point of reference is his incarnate Lord, whose presence is continually mediated by the sacramental church. This fact must be borne in mind if one is to grasp the full significance of More's appeal to conscience. This appeal, which reaches its high point during the period of the composition of the Tower Works ${ }^{27}$ was neither a retreat into solitary selfhood nor a flight into an ecclesiastical womb. It was instead an affirmation of the inviolability of

23 Richard S. Sylvester, "Conscience and Consciousness: Thomas More," in The Author in His Work: Essays on a Problem in Criticism, ed. Louis L. Martz and Aubrey Williams (New Haven, CT: Yale University, 1978) 163-74, at 165, 172. See also Sylvester, "Roper's 'Life of More,"” Moreana 36 (1972) 47-59; and Germain Marc'hadour, "Saint Thomas More and Conscience," Moreana 30 (1993) 55-64, at 62, where Marc'hadour notes that the word "conscience" refers to "a cognitive dimension of con-science," an "element that is easily lost sight of because one associates ['conscience'] with consciousness." However, as the author points out, "in other languages, French notably, one noun, conscience embraces both the mental and the moral domains, though the corresponding adjectives are two: conscient and consciencieux."

${ }^{24}$ Miller, "Heart of the Final Struggle" 123.

25 Seymour Baker House, “The Field Is Won': An Introduction to the Tower Works," in A Companion to Thomas More, ed. A. D. Cousins and Damian Grace (Madison, NJ: Farleigh Dickinson University, 2009) 225-42, at 240-41.

${ }^{26}$ House, "“The Field Is Won"” 240.

27 See Louis L. Martz, "Introduction: The Tower Works," in A Dialogue of Comfort against Tribulation, ed. Louis L. Martz and Frank Manley, Yale Edition of the Complete Works of St. Thomas More 12 (New Haven, CT: Yale University, 1976) lvii-lxxxvi, at lxi. See also De Silva, "Good Company" 1-25, at 11-12. 
the intimate relationship that exists between the self and its Creator, and that is mediated by membership in the visible communion of the church ${ }^{28}$ More's appeal to conscience was an expression of his determination to delimit and secure that sacred space within which the self most truly lives and moves and has its being. Henry VIII's usurpation of authority was an encroachment on that space, an attempt to reconfigure it that had to be resisted.

For More, then, conscience is best understood as both the consciousness that one exists in relationship to God as a responsible subject, or self, and the summons to act in accord with this consciousness. In short, to be faithful to conscience means to act responsibly in the light of one's knowledge of one's duty. ${ }^{29}$ For More, the jurist, this translated into the realization (and conviction) that he must ultimately provide an account of himself before the highest court of all, the court of heaven. ${ }^{30}$

Newman's thought on conscience both complements and extends More's basic insights. It is to Newman that I now turn.

\section{John Henry Newman on Conscience and Selfhood}

It is basic to Newman's theological anthropology that the human subject is "emphatically self-made" and charged with the task of "completing his inchoate and rudimental nature, and of developing his own perfection out of the living elements with which his mind began to be." 31 In his Philosophical Notebook, Newman observed, "Being is not known directly, but indirectly through its states." 32 Among those "primary conditions [or "operations"] of the mind which are involved in the fact of existence,"

28 See Louis L. Martz, "Thomas More: The Sacramental Life," Thought 52 (1977) 300-318, at 314; Katherine Gardiner Rodgers, "The Lessons of Gethsemane: De tristitia Christi," in Cambridge Companion to Thomas More 239-62, at 249. Compare John Henry Newman, Apologia Pro Vita Sua, ed. Martin J. Svaglic (Oxford: Clarendon, 1967) 18.

29 See Alison V. Scott, "More's Letters and 'The Comfort of the Truth," in $A$ Companion to Thomas More 53-76, at 68 where Scott notes that, "in More's perception and construction of conscience" in his last letters, "conscience represents the proof of his self-knowledge and religious faith at the same time as it functions as a response to God's word (the fulfilment of a duty)."

30 This is why More repeatedly insisted that he had no intention of "pinning" his soul "at another man's back" (Marc'hadour, "Saint Thomas More and Conscience" 55-64, esp. 56-57). More's attitude toward heresy and heretics is a controverted topic. For an extended and nuanced discussion of this theme, see Richard Rex, "Thomas More and the Heretics: Statesman or Fanatic?," in Cambridge Companion to Thomas More 93-115, at 108-12.

31 John Henry Newman, An Essay in Aid of a Grammar of Assent, ed. Ian Ker (Oxford: Clarendon, 1985) 229.

32 John Henry Newman, The Philosophical Notebook of John Henry Newman, ed. Edward Sillem, 2 vols. (Louvain: Nauwelaerts, 1969-1970) 2:43; see also 2:33-34. 
Newman included "not only memory, sensation, [and] reasoning, but also conscience." "33 Hence, for Newman it is as legitimate to say "conscientiam habeo ergo sum" or even "sentio ergo sum" as it is to say "cogito ergo sum." "34

Newman's views on consciousness (and conscience as a dimension of consciousness) are captured in Bernard Lonergan's understanding of consciousness as a set of "operations" that are, so to speak, simply given. As Fred Lawrence explains, for Lonergan "all the acts of consciousness except decision are not human actions in the ordinary sense. . . They occur to one in a way that is irreducible to one's own doing." ${ }^{35}$ Consciousness, then, which includes the experience of conscience, might be described in Lonerganian terms as "pure experience in the sense that, as an internal experience, it [conscience] is a mode of consciousness as distinct from self-knowledge." ${ }^{36}$ The operations of consciousness need to be "focused upon, explicitated, and thematized" for them to become "knowledge in the proper sense of the term." As Lawrence explains, this is achieved "through introspection, through inquiry and understanding and articulation, as well as through reflection and judgment."37

Newman's lifelong quest to develop a convincing articulation of his argument for God's existence from the experience of conscience is testimony to his awareness that so-called "pure experience" must be rendered intelligible. The same awareness is evident in his claim that it is "very doubtful" whether the experience of conscience would yield any insight

33 Ibid. 2:43. See also 2:35, where Newman writes: "Certain faculties then, or rather their operations, are a part of the initial idea of existence."

34 "Consciousness indeed is not of simple being, but of action or passion, of which pain is one form. I am conscious that I am, because I am conscious I am thinking (cogito ergo sum) or feeling, or remembering, or comparing, or exercising discourse" (ibid. 2:33); see also 2:35, 37, 41, 45, 63, 69, 73, 83.

35 Fred Lawrence, "The Fragility of Consciousness: Lonergan and the Postmodern Concern for the Other," Theological Studies 54 (1993) 55-94, at 83, emphasis original.

36 Lawrence, "Fragility of Consciousness" 70. Lawrence references Bernard Lonergan, "Existenz and Aggiornamento," in Collection: Papers by Bernard Lonergan, ed. F. E. Crowe (London: Darton, Longman, \& Todd, 1967) 240-51, at 248-49.

37 Lawrence, "Fragility of Consciousness" 70. Lawrence refers to Bernard Lonergan, "Christ as Subject: A Reply," in Collection 164-97, at 178-80. I see a striking parallel between Newman's reflections on the "operations" of consciousness and Lonergan's treatment of the theme, and a case might well be made for direct influence in this regard. However, such an analysis is beyond the scope of this paper. It is, in any case, striking that Lonergan's references to Newman most often concern the latter's appeal to conscience. George S. Worgul, "The Ghost of Newman in the Lonergan Corpus," Modern Schoolman 54 (1977) 317-32, at 319, points out that "Newman and Lonergan both use the actual performance of the human mind as their starting point" and that "both commence their work with a phenomenology of intelligence as it appears operative in concrete life." 
at all if it were not supplemented by "education, social intercourse, experience, and literature." 38

According to Newman, conscience is characterized by two indivisible, but not indistinguishable, dimensions that he described as a "moral sense" and a "sense of duty." As a "moral sense," conscience is manifest in the awareness that "there is a right and a wrong," which is not, of course, the same as knowing, in a particular instance, what is right or wrong. ${ }^{39}$ As a "sense of duty," conscience is manifest as a "keen sense of obligation and responsibility," namely, to do good and avoid evil. ${ }^{40}$ Newman speaks of these two dimensions, respectively, as "a rule of right conduct" and "a sanction of right conduct." 41

We are reminded here of More's acknowledgment that conscience involves both a consciousness of responsibility and a call to accountability. For Newman, then, as for More, conscience is related, in the first place, to action or performance (i.e., to ethics). This is the key parallel between the two thinkers. Newman, however, does something that was clearly impossible for More: he subjects his experience to what is perhaps best described as a phenomenological reflection. For More, the notion of conscience was of a piece with the self-evident religiosity of medieval culture. For the 19th-century Newman, however, religion was clearly in retreat, and his ruminations on conscience are, at least in part, an attempt to come to terms with this decline.

According to Newman, it is peculiar to conscience that it "has an intimate bearing on our affections and emotions." Indeed, in Newman's view, conscience "is always emotional." Hence, he sometimes speaks quite simply of "the feeling of conscience" to describe its operation. ${ }^{42}$ Newman describes this feeling as "a certain keen sensibility, pleasant or painfulself-approval and hope, or compunction and fear" that follows upon the performance of certain actions. ${ }^{43}$

38 On Newman's attempts to develop a philosophical version of his argument from conscience (a "proof of theism"), see his Philosophical Notebook 2:31-78. For his thoughts on the need for the personal appropriation of the experience of conscience, see Grammar of Assent 79-80.

39 Newman, Grammar of Assent 74. See also De Silva, "Good Company" 9-11, where he appeals to Newman to elucidate More's understanding of conscience.

${ }^{40}$ Newman, Grammar of Assent 74; see also 105 and Philosophical Notebook 2:49.

41 Newman, Grammar of Assent 74.

42 Ibid. 75. See also Philosophical Notebook 2:49.

43 Newman, Grammar of Assent 73. Newman's reflections on conscience predate Freud's psychoanalytic considerations of the same, but the latter do not undermine Newman's approach. Perhaps the most significant difference is Newman's insistence that the experience of conscience is not reducible to guilt. Instead, it is characterized by the persistence of the hope that comes to expression in the continued practice of religion and the anticipation of a liberating word or revelation from the deity. For more detailed discussion of Newman's views in the light of a Freudian critique, see Terrence Merrigan, “'Myself and My Creator': Newman and 
For Newman, the feelings generated by conscience are possessed of profound theological significance:

These feelings [of shame or self-approbation] in us are such as require for their exciting cause an intelligent being. . . . If the cause of these emotions does not belong to this visible world, the Object to which [our] perception is directed must be Supernatural and Divine; and thus the phenomena of Conscience, as a dictate, avail to impress the imagination with the picture of a Supreme Governor, a Judge, holy, just, powerful, all-seeing, retributive. ${ }^{44}$

As I have already indicated, Newman was aware that the intimations of the divine presence furnished by conscience and traced by the religious imagination need to be deepened and refined through experience and reflection. ${ }^{45}$ Moreover, the presence of an "image" in the mind (or, more accurately, the imagination) does not, by itself, constitute a proof of God's existence. ${ }^{46}$ It does, however, provide fertile ground for the eventual acceptance of this great truth: "Conscience is nearer to me than any other means of knowledge; and being carried about by every individual in his own breast, and requiring nothing besides itself, it is thus adapted for the communication to each separately of that knowledge which is most momentous to him individually." 47

So Newman can write that the existence of God "is more intimately connected with the nature of the human mind itself than any thing else, and while it is to be received on faith, [it] hardly is so in fact"; 48 and Jan Walgrave could marvel at Newman's "astonishing" view that, in the order of certitudes, the belief in an external world occupies the third place after the certitude of one's own existence and of the existence of God. ${ }^{49}$

For Newman, then, "conscientiam habeo, ergo sum" is also-and more or less simultaneously_"conscientaim habeo, ergo Deus est." 50 This conviction explains Newman's often-cited remark that, for him, there were

the Modern Subject," in Newman and Truth, ed. Terrence Merrigan and Ian Ker (Grand Rapids, MI: Eerdmans, 2008) 1-33, at 24-27; John F. Crosby, Personalist Papers (Washington: Catholic University of America, 2004) 93-112; Ronald Ledek, The Nature of Conscience and Its Religious Significance with Special Reference to John Henry Newman (San Francisco: International Scholars, 1996) 57-83.

${ }^{44}$ Newman, Grammar of Assent 76, emphasis added; see Terrence Merrigan, "The Image of the Word: John Henry Newman and John Hick on the Place of Christ in Christianity," in Newman and the Word, ed. Terrence Merrigan and Ian Ker (Leuven: Peeters, 2000) 1-47.

45 Newman, Grammar of Assent 80.

46 See ibid. 75-83 (esp. 79), 251-63; and Philosophical Notebook 2:59, 39, 43.

47 Newman, Grammar of Assent 251; see also Newman, Philosophical Notebook $2: 39,41-42$.

${ }^{48}$ Newman, Philosophical Notebook 2:43.

49 Jan H. Walgrave, "Conscience de Soi et conscience de Dieu: Notes sur le 'Cahier philosophique' de Newman," Revue Thomiste 71 (1971) 367-80, at 379.

50 Newman, Philosophical Notebook 2:59. 
"two and two only absolute and luminously self-evident beings, myself and my Creator." ${ }^{51}$ It accounts, too, for his declaration that "if I am asked why I believe in God, I answer that it is because I believe in myself, for I feel it impossible to believe in my own existence (and of that fact I am quite sure) without believing also in the existence of Him, who lives as a Personal, All-seeing, All-judging Being in my conscience." 52

In the final analysis, Newman's phenomenological reflections might be seen as putting flesh on the bones of More's fundamental conviction that, in the experience of conscience, the subject apprehends not only itself but also itself as a subject in relation to God. The implications of this apprehension, for both More and Newman, will now be considered.

\section{THE FASHIONING OF THE SELF IN MORE AND NEWMAN}

\section{The Notion of Self-Fashioning}

In 1980, Stephen Greenblatt, with a book entitled Renaissance SelfFashioning: From More to Shakespeare, launched something of a revolution in Renaissance studies, including the study of Thomas More. Greenblatt's major thesis was that the 16th century brought with it a renewed awareness that "selfhood" was, in many respects, a human construct, a "project" that the enterprising individual could initiate and shape, and even manipulate, always, however, in response to a context that he or she did not control. ${ }^{53}$

John Jeffries Martin, however, has taken Greenblatt to task for portraying the Renaissance "subject" as a "precursor to our own contemporary views of the self as divided, fragmented, even illusory," as "all artifice and surface,

51 Newman, Apologia Pro Vita Sua 18.

52 Ibid. 180. See also Newman, Philosophical Notebook 2:31, where he observes that his own view was that "there is a God, because there is a moral obligation." See Philip C. Rule, Coleridge and Newman: The Centrality of Conscience (New York: Fordham University, 2004) 41-64; and on conscience as consciousness of moral responsibility, see 57, 63-64.

53 Stephen Greenblatt, Renaissance Self-Fashioning: From More to Shakespeare (Chicago: University of Chicago, 1980, 2005). The 2005 edition contains a new preface (xi-xvii) entitled "Fashioning Renaissance Self-Fashioning," in which Greenblatt reflects on the context in which the 1980 edition was written. The threat to inwardness posed by modernity and postmodernity has been addressed by Marilynne Robinson, Absence of Mind (New Haven, CT: Yale University, 2010). According to her, "the core assumption that remains unchallenged and unquestioned" in "modern" thought is "that the experience and testimony of the individual mind is to be explained away, excluded from consideration when any rational account is made of the nature of human being and of being altogether" (ibid. 22). For a discussion of the place of the subject in modern theology, see Terrence Merrigan, "Theology and the Appropriation of the Existentialist Tradition," in Theology and Philosophy: Faith and Reason, ed. Oliver D. Crisp et al. (London: T. \& T. Clark, 2012) 156-70, at 163-66. 
devoid of interiority and inwardness-as something contingent, constructed, and "fashioned." 54 Martin is particularly troubled by the postmodern view of the subject as "one in which the social world not only takes priority but actually dominates any experience of interiority or inwardness." ${ }^{" 55}$ While Greenblatt does indeed acknowledge that "one of the principles of [his] book is that the dream of autonomous agency, though intensely experienced and tenaciously embraced, is only a dream," he also acknowledges and endorses "the need to sustain the illusion that I am the principal maker of my own identity." Renaissance subject seems to accord better with the record of Thomas More's struggles at self-definition. According to Martin, "Renaissance identities (no matter which particular form they assumed) were almost always anxious identities, uncertain about the nature of the boundaries between what not only well-known writers and artists but also ordinary men and women viewed as a kind of wall between the inner and the outer self." ${ }^{\circ 7}$ The self, in this context, "is discerned most clearly as a relation between those dimensions of experience that people describe as internal (conscious or unconscious thoughts, feelings, beliefs, emotions, desires) and those they describe as external (speaking or writing, hating or loving, praying or blaspheming, laughing or crying, stealing or buying, and so on)." This Renaissance self, "while protean, was almost always understood as the enigmatic relation of the interior life to life in society." 60 While the Renaissance self "could be defined by social location," it was also defined "by a selfconscious awareness of the complexity of community." "1

Martin's view of the Renaissance self, namely, that it was always marked by "self-consciousness about interior experience or inwardness or the tensions that existed between such inwardness and one's stance in the world," ${ }^{2}$ would certainly seem to apply in the case of More. According to Martin, "the defining problem of identity in the Renaissance" was precisely "the question of how the experience of the inner world of each person was related to the larger social environment in which he or she lived," such that "the self was experienced as something in which one's internal perceptions and beliefs either were or were not at home in the larger world." 63

The conviction that the subject could, so to speak, "fashion" itself, was not entirely novel, but the 16th century offered new possibilities for its

\footnotetext{
54 John Jeffries Martin, Myths of Renaissance Individualism (New York: Palgrave Macmillan, 2004) 11, 127.

55 Ibid. 16.

56 Greenblatt, Renaissance Self-Fashioning x, 257.

57 Martin, Myths of Renaissance Individualism 13.

58 Ibid. 14.

60 Ibid. 16 .

62 Ibid. 18.
59 Ibid. 15.
61 Ibid. 17-18.

63 Ibid. 131.
} 
realization. Greenblatt was especially interested in the conditions under which identities are generated, and the inevitable tensions that arise between the prevailing structures and the aspirations of the subject or self that seeks to establish its own particular identity. In the cases considered by Greenblatt, including that of Thomas More, the "subjects under construction," so speak, were obliged to contend with three factors in particular: (1) their commitment (or "submission") to "an absolute power or authority situated at least partially outside the self" (such as God or an institution); (2) their relation to some alien or hostile "other" (such as the heretic or the savage) which has to be resisted; and (3) the essential ambiguity of their own struggle, that is to say, the fact that the conflict they engaged in was at once deeply felt and very personal. ${ }^{64}$

One might recast Greenblatt's threefold categorization as (1) the struggle against solipsism, (2) the struggle with the threatening "other," and (3) the struggle with the ambiguity of history. ${ }^{65}$ While Greenblatt was clearly not interested in applying his triad to Newman, I see good reason to do so. Like More, Newman was convinced that "self-fashioning" is a moral and religious duty, one that is inherent in our condition as beings in an imperfect world. The striking parallels between the struggles of both men to achieve selfhood I consider in the following reflections.

\section{Self-Fashioning and the Struggle against Solipsism}

Students of More and Newman have always been intrigued by their paradoxical and multifaceted personalities. Both men have, therefore, been the objects of an "extraordinary medley of verdicts." ${ }^{66}$ In More's case, the focus of these disparate assessments is usually his alleged transformation from Renaissance humanist and author of Utopia to robust opponent of heretics, author of blistering tirades against Protestant Reformers, and martyr for papal supremacy. ${ }^{67}$ In Newman's case, what has troubled many

${ }^{64}$ Greenblatt, Renaissance Self-Fashioning 9. Greenblatt identifies "a set of [ten] governing conditions common to most instances of self-fashioning." He summarizes them: "We may say that self-fashioning occurs at the point of encounter between an authority and an alien, that what is produced in this encounter partakes of both the authority and the alien that is marked for attack, and hence that any achieved identity always contains within itself the signs of its own subversion or loss" (ibid.).

65 Ibid. Greenblatt notes that the process of self-fashioning was "always, though not exclusively, in language." This is true of both More and Newman, but I cannot here address this aspect of their self-fashioning.

66 Newman, Philosophical Notebook 1:20. In this volume, editor Edward Sillem considers the diverse interpretations of Newman.

${ }^{67}$ For a listing of the paradoxes characteristic of More, see Marius, Thomas More 519; and C. S. Lewis, English Literature in the Sixteenth Century (Oxford: Clarendon, 1954) 170, 180-81. 
non-Catholic commentators is his decision to submit his agile-and even skeptical-mind to an authoritarian and allegedly backward-looking church. In both cases, the suspicion is often voiced that they were motivated by a deep-seated and perhaps even unconscious longing to find intellectual and emotional security in the safe haven of Rome.

A more convincing explanation of the apparent shifts in conviction might be sought in what one commentator on More has described as the "inner man," that is to say, the conscientious self (or subject) endeavoring to remain faithful to its essential vocation. ${ }^{68}$ "Essential" here refers to "that which determines the very being of a person or thing." The inner man, the inner self, exists as a sort of "private retreat," 69 and both More and Newman turned to it often. In the so-called "real" world, however, the conscientious individual is, as it were, condemned to move between "his public persona and his inner self." ${ }^{70}$ In this regard, it is interesting to note that both More and Newman were men of action, acutely sensitive to the spirit of their times, and prepared to engage with the world in defense of their deepest convictions. And yet neither man seems to have taken the world completely seriously, which is not the same as saying they did not think that the business of the world was a serious matter.

There is a remarkable parallel between More's conviction that life is best understood as a play in which we are assigned a variety of roles, and Newman's conviction that the "real" world is invisible. ${ }^{71}$ Of course, in the case of both thinkers, the origins of these attitudes can be traced, in part, to very specific influences. More inherited the medieval tradition of the memento mori meditations that he in turn cultivated, ${ }^{72}$ and Newman's temperament and his patristic studies reinforced his sense of the unreality of the visible world. ${ }^{73}$ Nevertheless, it is clear that both men consciously chose to give pride of place to their inner life in the determination of their attitudes toward the world and their place in it. And both developed a rigorous religious discipline to sustain that determination.

68 Louis Martz, The Search for the Inner Man (New Haven, CT: Yale University, 1990) 21, 27, 92, 96. Greenblatt, Renaissance Self-Fashioning 68, speaks of the "inner self."

69 Greenblatt, Renaissance Self-Fashioning 45, 68.

70 Ibid. 45-46. More actually built a "private retreat," a place of prayer and meditation, to which he retired at regular intervals to contemplate his mortality.

71 Ibid. 27. Greenblatt also notes here that "the theatrical metaphor was More's favorite." On Newman's sense of the invisible world, see his Apologia Pro Vita Sua 36-37; and Louis Bouyer, "Newman and English Platonism," Monastic Studies 1 (1963) 111-31.

${ }^{72}$ See Germain Marc'hadour, "Thomas More's Spirituality," in St. Thomas More: Action and Contemplation, ed. Richard S. Sylvester (New Haven, CT: Yale University, 1972) 125-59, at 131-34.

73 Newman, Apologia Pro Vita Sua 18, 36-37. 
In both men, too, the process of self-actualization, so to speak, might well be described as "the coming into being of a new self, a more meaningfully integrated self." This "new" self was "a self which the person's life and situation 'called for'; but what is 'called for' is not uniquely fixed by the preceding circumstances. It is something which is in part an invention, a creation," but it does not lack constancy. It is instead-and always-a "unique integration, one of a limited but not exhaustively specifiable range of possible selves, any one of which would do what is called for." Hence, "although there is a kind of radical gap between the old self and the new, there is also an essential continuity," a continuity constituted by the willingness of the self to surrender itself "to a new and unknown form of integrity." And the new "self" takes the old self "and the effects of its acts as a legitimate heritage, a heritage neither rejected as unfair nor considered as alien and repressed." 74 This emerging self is shaped above all by the call to act responsibly or, perhaps more accurately, to assume responsibility. Responsibility here is to be understood "in its primary sense" as "commitment, not obligation. Indeed, genuine obligations arise out of commitments."

For neither More nor Newman, however, did the commitment to the inner self issue in solipsism. When More was compelled to disclose and justify the stand taken by his inner self, he appealed - in what seems at first to be a contradiction - to the "mind of the Church." As he explained to his daughter, "I am not then bounden to change my conscience and conf[o]rm it to the council of one realm, against the general council of Christendom." Greenblatt observes, in More's last letters, his conscience "comes to be identified more and more powerfully and directly with this communal solidarity, as if the final weeks had burned away all that stood between his intimate sense of himself and the great consensus of Christendom with which he longed to merge." At the end of his life, when More talks about his conscience, "he speaks at once of his innermost being and his participation in the community, the communion, of all true Christians, past, present, and future, in the visible body of the Catholic Church.",77

For Newman, too, the religious consciousness born of adherence to conscience (what Newman called "natural religion") must be complementedor, more accurately, completed-by Christian (and Catholic) faith. Conscience alone cannot sustain the moral and religious commitment it urges upon us. Its call to holiness and goodness finds no echo in the

74 For this notion of the "emergent self," I am indebted to Herbert Fingarette, The Self in Transformation: Psychoanalysis, Philosophy, and the Life of the Spirit (New York: Basic Books, 1963) 104-5.

75 Ibid. 101.

76 De Silva, Last Letters 60. The letter dates from about April 17, 1534. The original text employs confirm for conform.

77 Greenblatt, Renaissance Self-Fashioning 69-70. 
world; its injunctions appear increasingly impracticable; and the image of God it engenders looks increasingly like a childish fantasy. Left to itself, conscience inevitably withers, choked by the vision of things that the "real" world relentlessly propagates. ${ }^{78}$ To Newman's mind, only the church-and for the mature Newman, only the Roman Catholic Church-could serve as "the sufficient champion" of "the whisper of a law of moral truth within," that is to say, of those "truths which the natural heart admits in their substance, though it cannot maintain - the being of a God, the certainty of future retribution, the claims of the moral law, the reality of sin, the hope of supernatural help." Of these truths, Newman insists, "the Church is in matter of fact the undaunted and the only defender.",79

\section{Self-Fashioning and the Struggle with the Threatening Other}

Neither More nor Newman underestimated the power of the world over the soul. It has been said of Newman that he rarely enjoyed that blissful repose in the Divinity known to some of the great Christian mystics. Instead, he moved toward God haunted, as it were, by the "noise," the "weariness and dreariness," and the "sorrow" of the world. "We are between the two," Newman wrote, "the inward voice speaking one thing within us, and the world speaking another without us." ${ }^{80}$ The world here is, as Newman described it, "this perishing outward scene" of "time and sense," apparently "made for "pleasure," that "promises well" but ultimately fails to "fulfil." 81 Newman's profound awareness of the world's ominous shadow is evident in his most celebrated testimony to his spiritual life. There, he employs as a metaphor for the divine presence a "kindly light" that illuminates our path homeward amid the "encircling gloom." Our knowledge of God through conscience and revelation pierces but does not overcome the darkness of our earthly existence. In one of the most

78 John Henry Newman, The Idea of a University, ed. Ian Ker (Oxford: Clarendon, 1976) 414. On a number of occasions throughout his life, Newman reflected on the inability of "natural religion" to relieve the "disquiet" generated in the hearts of its adherents. These included conscience's lack of a sanction beyond itself for its elevated claims about the Moral Governor and Judge, the obscurity of the object of one's religious instincts and aspirations, and the sense of one's culpability and one's inadequacy to the moral task. See Terrence Merrigan, "'One Momentous Principle Which Enters into My Reasoning': The Unitive Function of Newman's Doctrine of Providence," Downside Review 108 (1990) 254-81, at 265-66; see also Merrigan, "Revelation," in The Cambridge Companion to John Henry Newman, ed. Ian Ker and Terrence Merrigan (New York: Cambridge University, 2009) 47-72, at 50-55.

${ }^{79}$ Newman, Idea of a University 414.

80 John Henry Newman, Parochial and Plain Sermons, 8 vols. (London: Rivingtons, 1868) 4:313-14.

${ }^{81}$ Ibid. $1: 23 ; 2: 18 ; 6: 87 ; 8: 135$. 
remarkable passages of the Apologia, Newman gives poignant expression to the dismay he experienced when he turned his gaze from the contemplation of his own soul to a consideration of the world:

Starting then with the being of a God (which is ... as certain to me as the certainty of my own existence ...), I look out of myself into the world of men, and there I see a sight which fills me with unspeakable distress. The world seems simply to give the lie to that great truth, of which my whole being is so full; and the effect upon me is in consequence, as a matter of necessity, as confusing as if it denied that I am in existence myself. $^{82}$

More, too, was obliged to confront the chasm that opened up between his most deeply held conviction and the testimony of the world without. In his last months, "the great champion of the cult of the saints and the doctrine of Purgatory," as Eamon Duffy calls him, ${ }^{83}$ witnessed the beginnings of a full-scale assault on the church and the traditions he loved so dearly. This meant that when More appealed to the visible, Catholic Church, he was appealing to a body that was rapidly disappearing from England. The drama (and perhaps even the irony) of his appeal is heightened by the fact that More had always reproached the Protestant Reformers for their claim that the true church is an invisible body. Now, alone in his cell, struggling to convince even those dearest to him that his refusal to submit to Henry VIII's demands was not folly, More could not fall back on the immediate and "tangible, institutional presence" of what he regarded as the guarantor of his conscience. ${ }^{84}$

Newman, too, struggled with the gap between the idea of the church to which he had committed himself and the reality of the church on the ground, so to speak. As an Anglican he had been forced to conclude that his via media was but a theory that had never been realized in history, a "paper religion" or "paper system" as he described it. ${ }^{85}$ As a Catholic he was forced to acknowledge that the church he had become part of was less than it might have been, tainted as it was by, among other things, clericalism, intellectual parochialism, and on occasion the ruthless exercise of power. Of course, Newman always insisted that he had no regrets about his accession to the Roman Catholic Church. Quite the contrary, he described the church as a

82 Newman, Apologia Pro Vita Sua 216.

83 Eamon Duffy, The Stripping of the Altars: Traditional Religion in England 1400-1580 (New Haven, CT: Yale University, 1992) 381.

84 Greenblatt acknowledges this fact: "By the time of More's imprisonment in the Tower, on April 17, 1534," the "one corps" of Christendom, i.e., the one church to which More appealed, "was far more an affirmation of religious belief than a recognized, tangible, institutional presence. More's appeals to the consensus . . . are appeals to something seen with the eyes of faith" (Renaissance Self-Fashioning 70).

85 Newman, Apologia Pro Vita Sua 70, 186. 
safe haven where his soul had found rest. ${ }^{86}$ Nevertheless, he was acutely aware of its shortcomings. In his celebrated "Preface" to the republication of his major work on Anglican ecclesiology, Newman developed an "apologia" for the Catholic Church "as it is," which rather ironically takes its lead from a vision of the church "as it should be." Both as an Anglican and as a Catholic, then, Newman unfolded his ecclesiology with a view to an ideal of the church that the existing church can only approximate. ${ }^{87}$

Both More and Newman, it might be said, were "visionary realists," committed Catholics with a strong sense of what the church was and a still stronger sense of what it was called to be. They resolved to embrace the tension this inevitably brought with it, and to take personal responsibility for their part in its resolution.

\section{Self-Fashioning and the Struggle with the Ambiguity of History}

Jan Walgrave contended that it was Newman's experience of the antinomy between the truth impressed on him by the testimony of conscience and the apparent denial of that truth evidenced in the tableau of human history that provided the greatest stimulus for his intellectual labors. And there is, indeed, a case to be made for the claim that Newman's whole apologetic is directed to the working out of an intelligible solution to the deeply felt conflict between "faith" and "sight." 88

More, too, especially in the period when the Reformation was making headway in England, struggled to resolve the conflict between his faith in Christ and the church and his growing sense that Christendom was on the verge of destruction. ${ }^{89}$ However, after his resignation as chancellor and especially during his imprisonment, More regained his equilibrium. ${ }^{90}$ The composition of the Tower Works served as both the occasion for, and the manifestation of, his renewed sense of identity and purpose. He had long regarded the world's imperfection as a constituent element of God's "deliberate design," as part and parcel of his providential ordering of history. ${ }^{91}$ Now he homed in on Christ's passion as the paradigmatic moment in which the meaning of history in its entirety is disclosed. ${ }^{92}$ The narrative

86 Ibid. 214.

87 On Newman's critical assessment of the actual working of the church, see Terrence Merrigan, “The 'Theological Imaginary' in History: John Henry Newman and the Catholic Theological Imagination," Louvain Studies 34 (2009-2010) $185-208$, at 203-5.

88 Newman, Parochial and Plain Sermons 4:178; 5:289; 7:30, 180.

89 See Alistair Fox, Thomas More: History and Providence (New Haven, CT: Yale University) 205, 210; see also 103, 107.

90
92
Ibid. 238. 
of Christ's sufferings provides the key to the "universal drama of faithfulness and betrayal," as well as a "mysterious image of future times." 93 What happened to Christ is what is happening to More and what will happen repeatedly throughout history. What makes all of this bearable and even meaningful is the fact-grasped in faith as a fundamental conviction-that it is all part of God's grand design. ${ }^{94}$ Once he had grasped this truth, More opted to play-with conviction-his "part" in the divine drama that was being authored and directed by God..$^{95}$

Alistair Fox claims that "one intellectual preoccupation links all of More's writings: [namely], his attempt to discover the precise nature of the divine providence by which he believed the world must be ruled." "Eventually," Fox continues, More's "whole doctrinal and intellectual position came to depend upon his view of universal history and the grand design of God." 96

In his preoccupation with providence, More bears yet again a striking resemblance to Newman. Confronted with the antinomy between faith and sight mentioned above, Newman too has recourse to the doctrine of providence, which he describes as that "momentous doctrine or principle, which enters into my own reasoning, and which another ignores." Newman's understanding of providence reveals that it has its roots in the fault line formed by the collision between the experience of God in conscience and the experience of the world's "godlessness." Indeed, for Newman, the experience of conscience is, so to speak, "pregnant" with the doctrine of providence. The doctrine possesses an immediate appeal to the child whose natural religious instincts have not been subverted. Such a child has "that within him which actually vibrates, responds, and gives a deep meaning to the lessons of his first teachers about the will and the providence of God." For the child "has in mind the image of an Invisible Being who exercises a particular providence among us, who is present everywhere, who is heart-rending, heart-changing, ever-accessible, open to impetration." 98

93 House, “"The Field Is Won'” 240; Fox states that, "By placing the passion in its universal context, More tried to show how it was the very linchpin of the whole grand design of God as far as human destiny was concerned." Fox also notes that "the archetypal, exemplary nature of the passion, More believed, had been determined by divine providence" (Thomas More 214, 244).

94 See Marius, Thomas More 515. See Fox, Thomas More 210.

95 See Fox, Thomas More 87, 93. Fox regards Augustine (and his De civitate Dei, in particular) as the most important source for More's understanding of God's providential guidance of history (ibid. 95-96).

96 Ibid. 76, 85, 95. I have borrowed the notion of More playing a part in the divine drama from Fox (ibid. 4).

97 Newman, Grammar of Assent 265.

98 Ibid. 77-79. See Merrigan, “'One Momentous Principle”” 257-61. 
The experience of life confirms this intimation of divine solicitude, at least for those who honor conscience. "Religious men cannot but feel, in various ways, that His providence is guiding them and blessing them personally, on the whole." "99 Indeed, this conviction is more akin to a conclusion grounded on experience than a matter of faith. The doctrine, says Newman, is the "portion" of "Natural Theology" "most on a level with the [empirical] sciences." ${ }^{100}$ Hence, he himself could pray as follows: "I require no faith, for I have had long experience, as to Thy providence towards me." 101 The perception of God's providential hand in history is the product of a reflective process, one that Newman commends to his fellow-believers, and that he himself practiced as a matter of course. The "noiseless," "yet restless" course of God's providences ${ }^{102}$ is audible only to the attentive ear of the conscientious listener. Where it is heard, however, it becomes, in the words of Walgrave, "the key to the enigma of the world and the uneasy state of religion in it." $" 103$

Newman provides a more comprehensive analysis of the relationship between conscience and providence than More, but both agree that faith in the latter doctrine is essential if one is to cope with the ambiguity of history. In this regard, it is worth recalling that a belief in divine providence was one of the three articles of faith that all citizens of More's Utopia were required to accept (along with the immortality of the soul and the existence of rewards and punishments after death). ${ }^{104}$

With their appeal to providence, More and Newman come full circle. They place their particular spiritual journeys resolutely within a broader, indeed a universal, framework. This does not rob their accounts of their specificity. Indeed, as Newman remarked in the Grammar of Assent, "in religious inquiry each of us can only speak for himself." But one may speak, in the hope that what satisfies oneself "is likely to satisfy others," and in the conviction that, if what is said is true, "it will approve itself to others also, for there is but one truth." ${ }^{105}$ Is there anything in the testimony of these two conscientious men that resonates with contemporary experience? This is the theme of my concluding reflections.

99 Newman, Parochial and Plain Sermons 6:248.

100 Newman, The Idea of a University 69. The original text speaks of the "human" sciences.

101 John Henry Newman, Meditations and Devotions of the Late Cardinal Newman, 3rd ed. (London: Longmans, Green, 1894) 585.

102 Newman, Parochial and Plain Sermons 2:109; 4:260.

103 J. H. Walgrave, Newman the Theologian (London: Geoffrey Chapman, 1960) 156.

${ }^{104}$ For a reflection on the origins of More's thought in this regard, see Stephen Greenblatt, The Swerve: How the World Became Modern (New York: W. W. Norton, 2011) 227-33.

105 Newman, Grammar of Assent 248. 


\section{MORE AND NEWMAN AND THE CONTEMPORARY QUEST FOR SELFHOOD}

\section{The Postmodern Context}

In his "Preface to A Man for All Seasons," Bolt, writing a little more than a half century ago, commented that we modern men and women not only feel but "know" that "the self is an equivocal commodity. There are fewer and fewer things that we 'cannot bring ourselves' to do. We can find almost no limits for ourselves other than the physical, which being physical are not optional." 106 The self Bolt describes is a self that has lost its moorings. In the course of the last 50 years, however, the self seems to have been set completely adrift, at least if so-called postmodern thinkers like Michel Foucault are to be believed. ${ }^{107}$

The precise nature of postmodernity—and by implication its relationship to modernity-is itself one of the topics preoccupying contemporary theorists in nearly all the human sciences. As one author has observed, the term "postmodernism," "like other categorical terms-say poststructuralism, or modernism, or romanticism, for that matter- . . suffers from a certain semantic instability: that is, no clear consensus about its meaning exists among scholars." 108

One prominent theorist, sociologist Zygmunt Bauman, distinguishes the terms postmodernity and postmodernism. According to him, postmodernism refers to "the collection of works of art or intellectual products created under the conditions, or within the period, of postmodernity." Postmodernity is the term used to describe a complex historical process that has been characterized, above all, by a radical clash of paradigms in "philosophy and the philosophically informed social sciences." This clash is manifest especially in the determination to challenge nearly all the accepted verities of modernity, particularly those that "went unnoticed" because they were simply taken for granted. Central among these are the convictions that underpinned "modernity's self-confidence," especially "its conviction of its own superiority over alternative forms of life, seen as historically or logically 'primitive'; and its belief that its pragmatic advantage over premodern societies and cultures, far from being a historical coincidence, can be shown to have objective, absolute foundations and universal validity." More concretely, postmodernity no longer endorses the "hierarchy of

106 Bolt "Preface to A Man For All Seasons" 477.

107 For a more extensive treatment of the idea of the postmodern subject, see Merrigan, "Myself and My Creator': Newman and the (Post-)Modern Subject" 9-15.

108 Ihab Hassan, "Toward a Concept of Postmodernism," in Postmodernism: A Reader, ed. Thomas Docherty (New York: Columbia University, 1993) 146-56, at 149 , emphasis original. 
values imposed upon the world" by the Eurocentric tradition of thought and practice. ${ }^{109}$ Every element in this worldview is now open to challenge.

It is not surprising, therefore, that one commentator has described postmodernity as characterized by "a vast will to unmaking," a tendency reflected in the preponderance of terms in postmodern discourse that denote "indeterminacy" (words such as "ambiguity," "decenterment," and "difference"). Such words are "signs" of a movement toward the deconstruction of every notion of a subject that is simply unmediated or self-grounding, ${ }^{110}$ whether that subject be the body politic or the individual psyche. ${ }^{111}$

In light of this evolution, Bauman is able to say that "the postmodern debate is about the self-consciousness of Western society, and the grounds (or the absence of grounds) for such consciousness." 112 Whereas modernity was, above all, the "era of certainty," especially regarding "the objective superiority" of Western rationality and culture, the "most poignant of the postmodern experiences is the lack of self-confidence."113

What is even more striking about postmodernity, however, is its abandonment of the quest for certainty, its willingness to live "life under conditions of permanent and incurable uncertainty." The postmodern has resigned himself to an existence lived "in the presence of an unlimited quantity of competing forms of life," none of which can "prove their claims to be grounded in anything more solid and binding than their own historically shaped conventions." 114 The most appropriate word to describe such a situation is perhaps not "pluralism," but rather "polycentrism." As David Tracy has pointed out, "there is no longer a Western cultural center with margins. There are many centers now, of which the West is merely one."115

109 Zygmunt Bauman, "The Fall of the Legislator," in Postmodernism: A Reader $128-40$, at $135-36$.

110 See David Tracy, Plurality and Ambiguity: Hermeneutics, Religion, Hope (San Francisco: Harper \& Row, 1989) 59. Tracy observes that Derrida's goal is "to produce a rhetoric of radical destabilization to expose any pretensions to full self-presence, any self-congratulatory Western resting in an untroubled, alinguistic, self-present, grounding ego."

111 Hassan, "Toward a Concept of Postmodernism" 153. Apropos of this, David Tracy writes: "A great deal of post-modern thought is directed towards exposing two illusions of modernity: the unreality of modernity's belief in self-presence in modernity's self-understanding as the present: and the unreality of the modern understanding of the autonomous, self-grounding self" ("The Post-Modern Re-Naming of God as Incomprehensible and Hidden," Cross Currents 50 [2000] 240-47, at 240, emphasis original).

112 Bauman, "Fall of the Legislator" 134, emphasis added.

113 Ibid. 135 emphasis original; see also 137, 138, 140.

114 Ibid. 135.

115 David Tracy, "Fragments: The Spiritual Situation of Our Times," in God, the Gift and Postmodernism, ed. John D. Caputo and Michael J. Scanlon (Bloomington, IN: Indiana University, 1999) 170-84, at 170. 
What divides the late modern from the postmodern understanding of the subject, then, would seem to be, above all, the question of whether the quest for subjectivity is worth undertaking. Indeed, for some postmoderns like Foucault, this quest is actually nefarious, a symptom of society's essential defect, namely, its tendency to totalitarianism, its urge to impose "sameness" on what is irreducibly different and unquantifiable. ${ }^{116}$ Accordingly, Foucault's position has been described as "anti-subjective." ${ }^{117}$ For him, the subject as such does not exist. The subject is the product of "haphazard, historical development." It is "always everywhere a fiction, and has no intrinsic reality or structure." The only identity that the (transient) subject can ever possess is the one that it "contrives" as an "alternative"- "albeit fanciful or ephemeral" to the identity that society seeks to impose on it. ${ }^{118}$

Ironically, then, the late-modern subject has been undone (or "deconstructed") by the relentless scrutiny of its basic structure undertaken during modernity. "The linguistic, psychoanalytic, ethical, and political critiques of the centered autonomous subject" 119 have exposed it as at best an illusion and at worst (as in Foucault's critique) a fraud perpetrated by vested interests.

While Foucault's antisubjectivist stance ${ }^{120}$ is admittedly an extreme position, it is useful as a means to highlight what is perhaps the most

116 Mansfield, Subjectivity 54-55.

117 Ibid. 36, 64, 10.

118 Ibid. 63-64, 179. Hassan describes the "two central, constitutive tendencies in postmodernism: one of indeterminacy, the other of immanence." The latter term refers to "the capacity of mind to generalize itself in symbols, intervene more and more into nature, act upon itself through its own abstractions and so become, increasingly, im-mediately [sic], its own environment" ("Toward a Concept of Postmodernism" 152-53).

119 Richard J. Bernstein, "Radical Plurality, Fearful Ambiguity, and Engaged Hope," review of David Tracy, Plurality and Ambiguity: Hermeneutics, Religion, Hope (San Francisco, CA: Harper \& Row, 1987), in Journal of Religion 69 (1989) $85-91$, at 89.

${ }^{120}$ On this point Mansfield writes: "To those who work with Foucault's ideas, subjectivity is always everywhere a fiction, and has no intrinsic reality or structure, neither one given to us at our birth or as a result of the relationships and experiences of our early lives. This fiction may be exploded, or remodeled as a subversion of the demands power places on us" (Subjectivity 64). Bernstein, "Radical Plurality, Fearful Ambiguity, and Engaged Hope," rightly challenges the meaningfulness of this sort of discourse. The philosophical notion of the subject (as distinct from the concrete and embodied human person) is also criticized by Vincent Descombes, "Apropos of the 'Critique of the Subject' and of the Critique of this Critique," in Who Comes After the Subject?, ed. Eduardo Cadava, Peter Connor, and Jean-Luc Nancy (New York: Routledge, 1991) 123-31, at 128. For a qualification of the view that Foucault (or at least, the later Foucault) "effaced" the subject, see Jacques Derrida, "Eating Well,' or the Calculation of the Subject: An Interview with Jacques Derrida," in Who Comes After the Subject? 96-119 at 97. 
alarming implication of all postmodern discourse, namely, the apparent death of ethics. According to Vincent Descombes, one critic of the modern and postmodern "critique of subjectivity," the ethical subject has no place in contemporary discourse. ${ }^{121}$ For most modern and postmodern thinkers, the "physical" or "empirical" entity cannot be identified "as the source of the operations that he believes ... to be his." 122 Descombes observes that at this point "the 'critique of the subject' appears in fact paradoxical, since it ends by saying that we really shouldn't attribute to someone his acts and gestures, unless by way of a "conventional fiction."” "But," he continues, "if we can never point to a human subject when it is a matter of answering the question Who?, it is, philosophically speaking, no longer possible to take practical questions seriously." The upshot is that "the philosophical subject, in its paradoxical version, if it is consistent, will stop short of developing a reflection upon the practical," by which Descombes means the ethical and the political. ${ }^{123}$

Tracy has also pointed to this dimension of the postmodern project. "With some notable exceptions," he observes, "too many post-modern thinkers feel free to deconstruct the history of past and present without actualizing any concrete ethical-political hope. They wish to deconstruct the status quo in favor of the fluxus quo." 124 If the subject-the self-is no more than "an obscure and shifting impersonal matrix of relationships, politics and bodies," "25 then it is meaningless to speak of personal responsibility or of obligation. After all, who is there to be responsible, to feel obligation? ${ }^{126}$

With regard to the theme of feeling, it is important to note that the postmodern deconstruction of the ethical subject is, at the same time, the deconstruction of the feeling subject. As Fredric Jameson observes, "The liberation, in contemporary society, from the older anomie of the centered subject [i.e., the Freudian subject engaged in the quest to overcome its alienation from its true self] may also mean, not merely a liberation from anxiety, but a liberation from every other kind of feeling as well, since there is no longer a self present to do the feeling." Jameson explains that this "waning of affect," as he calls it, does not mean that the postmodern condition is devoid of feeling, but it does mean that what feelings there are will be "free-floating and impersonal." 127

121 Descombes, "Apropos of the 'Critique of the Subject"” 123.

122 Ibid. 129.

124 Tracy, "Post-Modern Re-Naming of God" 244.

125 Mansfield, Subjectivity 174.

126 Descombes, "Apropos of the 'Critique of the Subject"” 130.

127 Frederic Jameson, "Postmodernism, or The Cultural Logic of Late Capitalism," in Postmodernism: A Reader 62-92, at 72. Jameson continues by observing: "This is not to say that the cultural products of the postmodern era are utterly 
In the light of the disappearance, so to speak, of any identifiable subject, Jameson comments that the shift from the late modern to the postmodern is essentially "one in which the alienation of the subject is displaced by the fragmentation of the subject." 128 Of course, as Foucault's thoroughgoing antisubjectivism illustrates, there is good reason to think that even the "fragmented" postmodern subject will fare no better than the much lamented Humpty Dumpty, namely, that after he has fallen, it will be wellnigh impossible to put him together again. The question, then, is whether his fall is inevitable. Is some other view of the subject possible, one that does justice to what is valuable in postmodern discourse without issuing in postmodern disintegration? I argue that More and Newman have a contribution to make in this regard.

\section{More, Newman, and the Postmodern Subject}

My reflection on the relationship between the understanding of the subject developed and exemplified by Newman and More and contemporary thought on subjectivity will be undertaken with a view to highlighting those dimensions of their thought that resonate with the major features of modern and postmodern proposals. The upshot of the comparison will be a view of Newman and More as thinkers who would not have been especially ill at ease in our modern and postmodern epoch, but who also represent a challenge to some of its tendencies. Three dimensions of the understanding of the subject developed by More and Newman would seem particularly pertinent to the contemporary debate, namely, their determination to do justice to the subject's historicity, ethical responsibility, and essential openness to the future. Let me examine each of these themes separately.

\section{The Historical Subject}

The self or subject described (and exemplified) by More and Newman is not the Cartesian res cogitans, that is to say, the self-grounding metaphysical subject of early modernity. ${ }^{129}$ Both Greenblatt and Martin, despite their disagreements, acknowledge as much when they seek to come to terms with More's determination to secure the integrity of the "inner self" that was continually being threatened by a culture that was in the process of

devoid of feeling, but rather that such feelings ... are now free-floating and impersonal, and tend to be dominated by a peculiar kind of euphoria." See also Mansfield, Subjectivity 165.

128 Jameson, "Postmodernism, or The Cultural Logic of Late Capitalism" 71 (emphasis added).

129 Descombes, "Apropos of the 'Critique of the Subject' and of the Critique of this Critique” 126. 
redefining itself. Newman's subject, too, is a humanized subject, ${ }^{130}$ a person of flesh and blood, a thinking, willing, feeling, imagining res extensa. So Newman could write, "Consciousness indeed is not of simple being, but of action or passion." 131 Sensitive as he was to the "fleshly" character of our being, Newman had no difficulty whatsoever in acknowledging that the subject's religious consciousness-i.e., its knowledge of God-is the fruit of its human development, including the whole process of socialization. Long before Karl Rahner employed the expression "mediated immediacy" to describe the way God discloses Godself to us in and through the created order, Newman testified to the principle in his description of conscience as the "echo" of God's voice in us. ${ }^{132}$ The God disclosed in conscience is the God whose presence is always mediated, whose voice is never heard directly but only as it is "echoed" in the chasms of our hearts and minds, and given laborious expression in the ambiguous history of the church. The believing subject cannot escape the demand to plumb her own depths, or the burden of interpretation imposed on her and her church by history.

\section{The Responsible Subject}

As indicated above, one of the great challenges facing the postmodern person is the question of the foundation of ethics. For both Newman and More, it is clear that this foundation is to be located in the essence of the subject itself, namely, in the self-consciousness that is the fruit of the experience of conscience. ${ }^{133}$

130 I have borrowed the notion of a humanized subject from Descombes: "In appearance, the 'critics of the subject' are opposed to the use of this concept whenever we speak of human affairs, whereas the 'defenders of the subject' wish to restore this concept to a central role. . . . But the quarrel [between 'critics' and 'defenders' of the subject] concerns the point of knowing whether it is appropriate to humanize or dehumanize this philosophical subject. The 'critics of the subject' are instead then critics of the human subject. They in no way refuse to differentiate between the human person (the 'physical' or 'empirical' entity, that which we can name, locate, etc.) and the true subject of human operations (such as thinking, willing, desiring, etc.). What they refuse is the possibility that the human being can identify himself as the source of operations that he believes, insofar as he is naïve (or mystified by the ideologies of subjectivity), to be his" (ibid. 129, emphasis original).

131 Newman, Philosophical Notebook 2:33.

132 Newman, Grammar of Assent 74-75. See Karl Rahner, Foundations of Christian Faith: An Introduction to the Idea of Christianity (New York: Crossroad, 1986) 83-84.

133 Robinson observes that, "While it may not have been true necessarily, it has been true in fact that the renunciation of religion in the name of reason and progress has been strongly associated with a curtailment of the assumed capacities of the mind" (Absence of Mind 75). This is especially evident in the case of the parascientific literature associated with Daniel Dennett and Richard Dawkins (see ibid. 41). 
Newman acknowledged that his claim on behalf of conscience, namely, that "it has a legitimate place among our mental acts," or "that we have by nature a conscience," constituted an unproved "assumption," a "first principle," the rejection of which made further discussion meaningless. ${ }^{134} \mathrm{He}$ makes no apology for this. In his Lectures on the Present Position of Catholics in England (1851), he declared that to think at all one must be possessed of at least some "opinions which are held without proof," and these are rightly called "first principles." 135

However, for Newman the "inevitability" of "first principles" does not divest the individual of responsibility in regard to them. It is basic to Newman's philosophical outlook that the human subject is "emphatically self-made" and charged with the task of "completing his inchoate and rudimental nature, and of developing his own perfection out of the living elements with which his mind began to be." 136 Where conscience is concerned, the implications of this claim are staggering. Not only is it one's "sacred duty" to acknowledge conscience's legitimate place among those "living elements" with which the mind begins (in accordance with "the law of our being"), the failure to do this prejudices, if it does not entirely pervert, the elaboration of a whole body of derivative principles. M. $\mathrm{H}$. Abrams, speaking of S. T. Coleridge's view of the origins of metaphysical systems, observes, "In Coleridge's opinion, a man is ultimately responsible for the kind of world he sees."137 Abrams might just as easily have been speaking of More or Newman, and the declaration could, indeed, be taken as a summary of their entire apologetic, since that apologetic is, in the final analysis, nothing other than a vindication of the religious interpretation of reality by an appeal to our ethical nature, which, for More and Newman, is synonymous with conscience.

In More's case, it was this conviction of the irreducibly personal character of one's religious judgments that allowed him in good conscience to say: "I would ... for mine own self follow mine own conscience, for which myself must make answer unto God, and . . . leave every other man to his own conscience." 138 It was the same conviction that allowed him to find

134 Newman, Grammar of Assent 73, 45-46.
135 John Henry Newman, The Present Position of Catholics in England (London:
ongmans, Green, 1903) 279 .
136 Newman, Grammar of Assent 225 .
137 M. H. Abrams, "Coleridge and the Romantic Vision of the World," in Coleridge's Variety: Bicentenary Studies, ed. John B. Beer (London: Macmillan, 1974) 101-33, at 126. See The Letters and Diaries of John Henry Newman, 32 vols., ed. C. S. Dessain and Thomas Gornall (Oxford: Clarendon, 1974) 25:280, where Newman says of his Grammar of Assent: "My book is to show that a right moral state of mind germinates or even generates good intellectual principles."

138 De Silva, Last Letters 94. 
peace with the decision of his nearest and dearest to submit to the demands of Henry VIII when he himself had determined that they were, quite literally, unconscionable. ${ }^{139}$

The subject described and exemplified by More and Newman is a subject under obligation, a practical or acting subject. Newman's thoroughly "ethicized" subject, whose motto is "Life is for action," 140 and More's "inner self," whose identity is determined (or defaced) precisely by the commitment to action, are treated in the next section.

\section{The Dynamic Subject}

The self or subject described (and exemplified) by More and Newman is a dynamic entity, a spiritual being engaged in a continual journey toward the mystery of justice and love first disclosed in conscience. One might even say that the self disclosed in the life and writings of More and Newman is engaged in a process of continual change or, perhaps more accurately, a process of endless "re-creation." However, there is also real continuity here, namely, the continuity provided by the One who calls the subject to authentic selfhood in love, and who stands as the guarantor of the meaningfulness of the process of growth and change. ${ }^{141}$

From the point of view of Newman's thought, the postmodern claim that the "subject" has no ground in and of itself is not at all alarming. The self is always being constituted by the "other"-the other for whom one is responsible, and the Other before whom one is responsible. The being of the self is, therefore, essentially gift (or grace) and task (or call), something to be actualized in every authentic response to the voice of conscience. ${ }^{142}$

139 The most poignant instance of this tension within More's family was his relationship with his daughter Margaret. John Guy, A Daughter's Love: Thomas and Margaret More (London: Fourth Estate, 2008), describes this relationship in some detail; see esp. 234-37, 247-50, 262-64).

140 Newman, Grammar of Assent 67.

141 The notion of God as the guarantor of the meaningfulness of the process of change and growth is the heart of Newman's doctrine of providence. For a recent reflection on the notion of providence (one that does not discuss Newman), see Genevieve Lloyd, Providence Lost (Cambridge, MA: Harvard University, 2008). Lloyd observes that the consequences of the loss of a belief in providence include the experience of "the uncontrollable as metaphysically threatening." In a context where belief in providence is abandoned, "human esteem rests on its capacity for control, [and] anxiety arises at having to admit the very existence of the uncontrollable" (ibid. 308).

${ }^{142}$ In a detailed study of Newman's understanding of conscience and its significance for both Newman's personal religious development and his theology, Walter E. Conn, drawing on the work of Bernard Lonergan, proposes that Newman's mature, but never systematically presented, view of conscience involved "three fundamental dimensions," namely, desire, discernment, and demand. These three 
Outside this response- that is to say, on every occasion when conscience is neglected or its claims denied-the subject is ungrounded and free-floating (just as Foucault describes it). It is, indeed, fragmentary and prey to the disparate longings arising from within or-what is more likely in our dayimposed upon one by an increasingly aggressive consumerist society.

For Newman and for More, the foundational experience that shapes selfhood always exists as a potential to be activated. Once it is activated, it sets one on the way toward the ground of one's being. ${ }^{143}$ In that sense, one might say that for More and Newman, the self is always "provisional."

Seen in this light, one of Newman's most cherished prayers takes on a new light. It seems a fitting text with which to conclude these reflections on the human subject who has never before in history been blessed with such possibilities and never seemed more uncertain of what to do with them.

I know, O my God, I must change, if I am to see Thy face!

... Oh, support me, as I proceed in this great, awful, happy change, with the grace of Thy unchangeableness.

My unchangeableness here below is perseverance in changing.

Let me day by day be moulded upon Thee, and be changed from glory to

glory, by ever looking towards Thee, and ever leaning on Thy arm....

All will turn to evil if I am not sustained by the Unchangeable;

all will turn to good if I have Jesus with me,

yesterday and today the same, and for ever. ${ }^{144}$

dimensions are "interlinked, unfolding facets of a single dynamic reality," which is the "cognitively, morally, affectively, and religiously conscious person, the existential self." For Conn, "the existential self $i$ s conscience," such that one can describe the human subject as "at root a divinely inspired and targeted desire for transcendence," which is manifest in the experience of conscience; a self "that struggles to discern what he or she should do in a particular situation of value"; and a self capable of a "practical judgment" that "demands to be followed, with disobedience resulting not in some external punishment but in a violation of one's very self, of one's desire, one's divine calling, to transcendence" (Conscience and Conversion in Newman: A Developmental Study of Self in John Henry Newman [Milwaukee.: Marquette University, 2010] 121-22, emphases original).

143 See the discussion in Crosby, Personalist Papers 110-11; and Terrence Merrigan, "Newman and Religious Experience," Divinising Experience: Essays in the History of Religious Experience from Origen to Ricœur, ed. Lieven Boeve and Laurence P. Hemming (Leuven: Peeters, 2004) 132-45.

144 John Henry Newman, Meditations and Devotions (London: Burns \& Oates, 1964) 58. 